\title{
Closing the Achievement Gap in P-12 Schools by Implementing Advanced Leadership Training and Comprehensive School Counseling Programs
}

\author{
Cynthia Palmer Mason \\ Aaron W. Hughey \\ Monica Galloway Burke \\ Western Kentucky University \\ United States
}

\begin{abstract}
This study was designed to examine the perceptions of educators and concerned citizens toward the academic achievement gap in P-12 schools. The participants were school administrators, school teachers, school counselors, parents, and concerned citizens. Those in each category were asked what they perceived to be important to decreasing the academic achievement gap. In addition, space was provided for each to identify what he/she thought would be most effective in decreasing the academic achievement gap and to write comments, suggestions, or concerns regarding the academic achievement gap in P-12 schools. Results of these findings suggest that most educators and citizens are concerned about the academic achievement gap in P-12 schools and they also feel that more can be done to diminish it. Lastly, implications for the implementation of advanced leadership training and comprehensive school counseling programs are explored.
\end{abstract}

Keywords: achievement gap, leadership training, school administrators, school counseling

This study examines the perceptions of school administrators, school counselors, school teachers, parents, and concerned citizens toward the academic achievement gap in P-12 schools. The achievement gap in education refers to the disparity in academic performance between groups of students. The achievement gap shows up in different academic measures; such as grades, standardized test scores, course selections, dropout rates, and college completion rates. It is most often used to describe the academic performance gaps between African American and Hispanic students, at the lower end of the performance scale, and non-Hispanic white students, and the similar academic disparity between students from low-income families and those who are better off (Editorial Projects in Education Research Center, 2011).

Research studies focusing on the causes of achievement gaps between low-income minority students and middleincome students have been ongoing since the 1966 publication of the report, Equality of Educational Opportunity (Equality of Educational Opportunity, 1966). This investigation was commissioned by the U.S. Department of Education. The results of that research indicated that both in-school factors and home/community factors impact the academic achievement of students and contribute to the gap.

For decades, policymakers, researchers, and school reformers have sought ways for schools to effectively address the achievement gap. One reason for the widespread concern over the gap in student achievement is that it involves substantial social and economic costs. Low educational achievement is associated with high unemployment, lower wages, greater dependency on welfare, and higher crime. Another reason for the widespread concern over the achievement gap is that the ethnic diversity of the U.S. population is increasingly growing and, by 2020, it is expected that school districts in most cities will have student populations that consist of predominantly students of color (Henig, Hula, Orr, \& Pedescleaux, 1999).

The focus on the academic achievement gap has intensified since the No Child Left Behind (NCLB) Act was passed in 2001. With the passage of NCLB, closing achievement gaps among various student groups became a priorityfor federal education accountability. Schools and districts were required to disaggregate student performance data to enable better comparisons between groups. This attention led to more targeted interventions for differentgroups of students; however, this has not closed most achievement gaps to an appreciable degree more than a decade since the law passed (Editorial Projects in Education Research Center, 2011).

Efforts to combat the gap have been numerous and have included reducing class sizes, creating smaller schools, expanding early-childhood programs, raising academic standards, improving the quality of teachers provided to poor and minority students, and encouraging more minority students to take high-level courses (Editorial Projects in 
Education Research Center, 2011). Although the achievement gap seems to have narrowed somewhat in recent years, there continues to be large disparities between black and white students and between Hispanic and white students in the U.S. (Achievement Gap, 2011).

Fensterwald (2013) reported on the latest results of the Program for International Student Assessment (PISA); this is an international test in math, science, and reading that is given in65 nations. The overall score of U.S. students in 2012 was below most industrialized nations and education systems. On this assessment, the United States scored below 29 nations in math, 22 nations in science, and 19 nations in reading.

Although schools have little influence over poverty or community factors, what happens in schools could lessen their negative impact (Holcomb-McCoy, 2007). With every passing year, the damage from the academic achievement gap continues to mount. Lower rates of high school graduation lead to less employment, higher rates of incarceration, substance abuse, ill health, and intergenerational poverty (Washington State Legislature, 2008). It seems reasonable to suggest that other measures to close the achievement gap in schools should be considered.

It is important to note that a growing body of research focuses on the significance of school leadership and school counseling programs. For instance, Dufour and Marzano (2011) noted the importance of school leadership. They examined how district, school, and classroom leaders can improve student achievement in Leaders of Learning. Also, Blasé and Blasé (2000) surveyed 800 American educators to gather information about the value of effective school leadership. Similarly, extensive research on schools suggests that leadership is not the sole responsibility of the school principal (Dollarhide, 2003; Hatch \& Bowers, 2002; Herr, 2001). The American School Counselor Association (ASCA) National Model (2006) sets precedence for school counselors to serve as school leaders. As a part of a comprehensive school counseling program, school counselors promote student achievement and systemic change that ensure equity and access to rigorous education for every student and lead to closing achievement, opportunity, and attainment gaps (Dahir \& Stone, 2009; Martin \& House, 2002).

\section{Method}

The design of this study emerged in response to the prevalence of the academic achievement gap in P-12 schools. The investigators developed an instrument to gather perceptions of the academic achievement gap in schools. They were particularly interested in the feelings of educators and concerned citizens about what they think is most important to decreasing the achievement gap in schools. The participants were school administrators, school counselors, school teachers, parents, and concerned citizens. They were asked to complete a self-report survey using an electronic platform (Qualtrics). Participants were contacted by e-mail and social media.

The survey instrument requested responses to two demographic items: (a) position as parent, teacher, school counselor, school administrator, or concerned citizen; and (b) level of education. These items were followed by eight statements that participants were asked to indicate their level of agreement on; their choices ranged from strongly agree to strongly disagree. In addition, there were two items at the end of the questionnaire that requested written responses. The first item asked each participant to indicate what he/she thought would be most effective in decreasing the academic achievement gap in P-12 schools; the second item asked each participant to make any comments, suggestions, or concerns regarding the academic achievement gap in P-12 schools. The investigators computed item-analysis for the data from the instruments to provide percentages for analysis and comparison.

\section{Results}

A questionnaire, designed by the investigators, served to collect data from the study participants. As shown in Table 1, a total of 136 respondents completed the survey. Of these 136respondents, 39 (28.68\%) were parents; $17(12.50 \%)$ were teachers; $2(1.47 \%)$ were school counselors; 5 (3.68\%) were school administrators; and $73(53.68 \%)$ were concerned citizens. In addition, of the 135 respondents who provided information indicating their educational attainment, $54(40.00 \%)$ indicated they had a high school or G.E.D. diploma; $14(10.37 \%)$ indicated they had an associate degree; $16(11.85 \%)$ indicated they earned a bachelor's degree; 21 (15.56\%) indicated they completed a master's degree; and $16(11.85 \%)$ indicated they had an advanced degree. 
Table 1. Level of Agreement with Statements Related to the Achievement Gap in P-12 Schools

\begin{tabular}{|c|c|c|c|c|c|c|c|}
\hline Statement & $\begin{array}{l}\text { Strongly } \\
\text { Agreed }\end{array}$ & Agreed & $\begin{array}{l}\text { Somewhat } \\
\text { Agree }\end{array}$ & $\begin{array}{l}\text { Neither } \\
\text { Agreed nor } \\
\text { Disagreed }\end{array}$ & $\begin{array}{l}\text { Somewhat } \\
\text { Disagreed }\end{array}$ & Disagreed & $\begin{array}{l}\text { Strongly } \\
\text { Disagreed }\end{array}$ \\
\hline $\begin{array}{l}\text { "I believe more can be done to } \\
\text { decrease the academic } \\
\text { achievement gap in P-12 } \\
\text { schools." }\end{array}$ & $\begin{array}{l}67 \\
(49.26 \%)\end{array}$ & $\begin{array}{l}46 \\
(33.82 \%)\end{array}$ & $\begin{array}{l}13 \\
(9.56 \%)\end{array}$ & $\begin{array}{l}5 \\
(3.68 \%)\end{array}$ & $\begin{array}{l}2 \\
(1.47 \%)\end{array}$ & $\begin{array}{l}1 \\
(0.74 \%)\end{array}$ & $\begin{array}{l}2 \\
(1.47 \%)\end{array}$ \\
\hline $\begin{array}{l}\text { "I think the required } \\
\text { professional development for } \\
\text { teachers should focus primarily } \\
\text { on enhancing academic } \\
\text { achievement." }\end{array}$ & $\begin{array}{l}57 \\
(41.91 \%)\end{array}$ & $\begin{array}{l}38 \\
(27.94 \%)\end{array}$ & $\begin{array}{l}33 \\
(24.26 \%)\end{array}$ & $\begin{array}{l}5 \\
(3.68 \%)\end{array}$ & $\begin{array}{l}1 \\
(0.74 \%)\end{array}$ & $\begin{array}{l}1 \\
(0.74 \%)\end{array}$ & $\begin{array}{l}1 \\
(0.74 \%)\end{array}$ \\
\hline $\begin{array}{l}\text { "I think teachers' annual } \\
\text { evaluations should reflect the } \\
\text { academic achievement of their } \\
\text { students." }\end{array}$ & $\begin{array}{l}42 \\
(30.88 \%)\end{array}$ & $\begin{array}{l}37 \\
(27.21 \%)\end{array}$ & $\begin{array}{l}37 \\
(27.21 \%)\end{array}$ & $\begin{array}{l}6 \\
(4.41 \%)\end{array}$ & $\begin{array}{l}7 \\
(5.15 \%)\end{array}$ & $\begin{array}{l}2 \\
(1.47 \%)\end{array}$ & $\begin{array}{l}5 \\
(3.68 \%)\end{array}$ \\
\hline $\begin{array}{l}\text { "I think school administrators } \\
\text { should be specifically trained } \\
\text { to impact the academic } \\
\text { achievement gap in their } \\
\text { schools." }\end{array}$ & $\begin{array}{l}61 \\
(45.19 \%)\end{array}$ & $\begin{array}{l}49 \\
(36.30 \%)\end{array}$ & $\begin{array}{l}20 \\
(14.81 \%)\end{array}$ & $\begin{array}{l}4 \\
(2.96 \%)\end{array}$ & $\begin{array}{l}0 \\
(0.00 \%)\end{array}$ & $\begin{array}{l}0 \\
(0.00 \%)\end{array}$ & $\begin{array}{l}1 \\
(0.74 \%)\end{array}$ \\
\hline $\begin{array}{l}\text { "I think each school should } \\
\text { provide after school tutoring in } \\
\text { reading and math in grades 1- } \\
\text { 5." } \\
\text { "I think elementary teachers in } \\
\text { grades } 1-5 \text { should be trained to }\end{array}$ & $\begin{array}{l}77 \\
(57.04 \%)\end{array}$ & $\begin{array}{l}37 \\
(27.41 \%)\end{array}$ & $\begin{array}{l}17 \\
(12.59 \%)\end{array}$ & $\begin{array}{l}2 \\
(1.48 \%)\end{array}$ & $\begin{array}{l}1 \\
(0.74 \%)\end{array}$ & $\begin{array}{l}0 \\
(0.00 \%)\end{array}$ & $\begin{array}{l}1 \\
(0.74 \%)\end{array}$ \\
\hline $\begin{array}{l}\text { evaluate academic performance } \\
\text { consistently, communicate } \\
\text { necessary information to } \\
\text { parents, and involve parents in } \\
\text { writing enhancement programs } \\
\text { for their children." }\end{array}$ & $\begin{array}{l}78 \\
(57.35 \%)\end{array}$ & $\begin{array}{l}42 \\
(30.88 \%)\end{array}$ & $\begin{array}{l}8 \\
(5.88 \%)\end{array}$ & $\begin{array}{l}5 \\
(3.68 \%)\end{array}$ & $\begin{array}{l}2 \\
(1.47 \%)\end{array}$ & $\begin{array}{l}0 \\
(0.00 \%)\end{array}$ & $\begin{array}{l}1 \\
(0.74 \%)\end{array}$ \\
\hline $\begin{array}{l}\text { "I think school counselors } \\
\text { should lead the efforts to } \\
\text { decrease the academic } \\
\text { achievement gaps in P-12 } \\
\text { schools." } \\
\text { "I think it is important for }\end{array}$ & $\begin{array}{l}46 \\
(34.07 \%)\end{array}$ & $\begin{array}{l}47 \\
(34.81 \%)\end{array}$ & $\begin{array}{l}21 \\
(15.56 \%)\end{array}$ & $\begin{array}{l}9 \\
(6.67 \%)\end{array}$ & $\begin{array}{l}5 \\
(3.70 \%)\end{array}$ & $\begin{array}{l}4 \\
(2.96 \%)\end{array}$ & $\begin{array}{l}3 \\
(2.22 \%)\end{array}$ \\
\hline $\begin{array}{l}\text { school principals to support the } \\
\text { efforts of school counselors as } \\
\text { they work to decrease the } \\
\text { academic achievement gaps in } \\
\text { P-12 schools." }\end{array}$ & $\begin{array}{l}77 \\
(57.04 \%)\end{array}$ & $\begin{array}{l}42 \\
(31.11 \%)\end{array}$ & $\begin{array}{l}10 \\
(7.41 \%)\end{array}$ & $\begin{array}{l}2 \\
(1.48 \%)\end{array}$ & $\begin{array}{l}2 \\
(1.48 \%)\end{array}$ & $\begin{array}{l}0 \\
(0.00 \%)\end{array}$ & $\begin{array}{l}2 \\
(1.48 \%)\end{array}$ \\
\hline
\end{tabular}

The results of the data analysis will follow the review of the research questions and the questionnaire. The four research questions this study posed follow:

1. Does it appear that participants believe that more can be done to decrease the academic achievement gap in P-12 schools?

2. What are the basic themes perceived as important to decreasing the academic achievement gap in P-12 schools?

3. Do the perceptions of these themes differ significantly by specific participants (parents, school teachers, school counselors, school administrators, concerned citizens)?

4. Do the perceptions of these themes differ significantly among participants by their educational level? 
On the questionnaire, participants were asked to indicate their level of agreement with statements related to the Achievement Gap in P-12 Schools (See Table 1). Results of the educators and concerned citizens' responses to all eight items on the survey indicate strong agreement with statements related to the Academic Achievement Gap inP-12 Schools. These results suggest that educators and other citizens are concerned with the achievement gap in schools and feel that more can be done to decrease the gap. For instance, $92.64 \%$ of all respondents indicated that they strongly agreed, agreed, or somewhat agreed that more can be done to decrease the academic achievement gapin P-12 schools; $94.11 \%$ of all respondents strongly agreed, agreed, or somewhat agreed that professional development for teachers should focus primarily on enhancing academic achievement; and $85.22 \%$ of all respondents suggest that teachers' annual evaluations should reflect the academic progress of their students.It is important to note that $96.30 \%$ of all respondents strongly agreed, agreed, or somewhat agreed that school administrators should be specifically trained to impact the academic achievement gap in their schools; $97.04 \%$ strongly agreed, agreed, or somewhat agreed that each school should provide after school tutoring in reading and math for grades $1-5$; and $94.11 \%$ of respondents strongly agreed, agreed, or somewhat agreed that elementary teachers in grades1-5 should be trained to evaluate academic performance consistently and communicate necessary information to parents/guardians.

In addition,84.44\% ofall participants indicated that they strongly agreed, agreed, or somewhat agreed that school counselors should lead the effort to decrease the academic achievement gaps in P-12 schools and 95.56\% of all participants strongly agreed, agreed, or somewhat agreed that it is important for school principals to support the efforts of school counselors as they work to decrease the academic achievement gaps in P-12 schools. These results indicate that educators and other citizens are concerned about the academic achievement gap in P-12 schools, that school administrators should be specifically trained to impact the academic achievement gap in their schools, and that school administrators should support the efforts of school counselors as they work to decrease the academic achievement gap in schools.

The first research question asked, "Does it appear that participants believe that more can be done to decrease the academic achievement gap in P-12 schools?" Results of item-analysis indicate that $92.64 \%$ of participants strongly agreed, agreed, or somewhat agreed that more can be done to decrease the achievement gap in schools. The implication of thee results will be discussed in the paragraph that summarizes the specifics of this study. The second research question asked, "What are the basic themes perceived as important to decreasing the academic achievement gap in P-12 schools?" Results of data analysis indicate that most comments seem to fit the basic themes of "professional development or training for educators, relationship building, and student assistance." The third research question asked, "Do the perceptions of these themes differ significantly by specific participants (parents, school counselors, school administrators, school teachers, and concerned citizens). The number of participants in each group is not the same; in fact, over $50 \%$ of the participants indicated that they are concerned citizens. However, the results of the responses from all participants indicate strong agreement on the basic themes perceived as important to decreasing the academic achievement gap in P-12 schools (96.30\% professional development or training for educators; $94.11 \%$ relationship building; $97.04 \%$ student assistance). These results seem to indicate no significant difference by specific participants.

The fourth research question asked, "Do the perceptions of these themes differ significantly among participants by their educational level?" As mentioned earlier, the number of participants in each group is not the same; however, itemanalysis of the responses from all participants indicate strong agreement on the basic themes perceived as important to decreasing the academic achievement gap in P-12 schools (96.30\% professional development or training for educators; 94.11\% relationship building; and $97.04 \%$ student assistance). This seems to indicate no significant difference by educational level.

The findings in this study compel the conclusions that participants (school counselors, school teachers, school administrators, parents, concerned citizens) are concerned about the academic achievement gap in P-12 schools and they believe that more can be done to decrease the achievement gaps in schools. In addition, the basic themes perceived as important to decreasing the academic achievement gap in P-12 schools are professional development or training for educators, relationship building, and student assistance. The perceptions of these themes neither differ by specific participants nor by educational level. These conclusions are supported by the results from dataanalysis.

\section{Discussion}

One of the major problems facing the educational system in the United States is the widespread inequity in educational achievement and opportunity across socioeconomic and ethnic groups. On a variety of measures, including high school completion, college enrollment, Advanced Placement course enrollment, and standardized achievement test scores, ethnically diverse (except Asian Americans) and low-income students have much lower levels of achievement (Holcomb-McCoy, 2007). 
Moreover, when reviewing college graduation statistics, young African Americans are only about half as likely as White students to earn a bachelor's degree by age 29 and young Latinos are only one-third as likely as Whites to earn a college degree (Haycock, 2001). This difference in achievement has become more widely known as the achievement gap and denotes when groups of students with relatively equal ability do not achieve in school at the same levels (Holcomb-McCoy).

Consequently, this study was designed to examine the perceptions of educators and concerned citizens toward the academic achievement gap in P-12 schools. The findings in this study compel the conclusion that the participants (school counselors, school teachers, school administrators, parents, concerned citizens) are concerned about the achievement gap in schools and feel that more can be done to decrease the gap. This conclusion is supported by results from data analysis. Also, participants were asked what they perceived to be most important to decreasing the academic achievement gap in schools and results of data analysis indicate that the basic themes perceived as important to decreasing the achievement gap in schools were professional development for educators, relationship building, and student assistance. This finding is supported by the analysis of written comments made by study participants.

Along these lines, $96.30 \%$ of all participants strongly agreed, agreed, or somewhat agreed that school administrators should be specifically trained to impact the academic achievement gap in P-12 schools; $84.44 \%$ of all participants strongly agreed, agreed, or somewhat agreed that school counselors should lead the effortto decrease the academic achievement gap in P-12 schools; and $95.56 \%$ of all participants strongly agreed, agreed, or somewhat agreed that it is important for school principals to support the efforts of school counselors as they work to decrease the academic achievement gap in P-12 schools. These findings are consistent with the growing body of research that focuses on the significance of school leadership and school counseling programs (Dufour \& Marzano, 2011; Blasé \& Blasé, 2000; Dahir\& Stone, 2009; Martin \& House, 2002).

In addition, the findings from this study are consistent with the concepts of Marzano, Waters, and McNulty (2005). They conducted a meta-analysis that included 69studies and created a list of 21 responsibilities that make an effective school leader. Engaging in productive communication with and among teachers and students was one of the most critical responsibilities. Also, the former Secretary of Education, Arne Duncan, focused on the need to strengthen school leadership and find better ways to train school principals in his address to the National Association of Secondary School Principals (Duncan, 2013).

Therefore, because of the documented significance of school leadership and the strong support for specific training for school administrators from participants in this study, it seems reasonable to recommend the implementation of lead management training for school administrators. Lead management is the term William Glasser $(1990,1991,1996)$ used to describe a democratic style of management and its accompanying communication techniques. The lead manager is in many ways the opposite of the boss manager. A significant difference in management styles between boss and lead management in schools is that the lead manager attempts to involve students, faculty, and staff in decision making; the lead manager also appeals to intrinsic motivation rather than relying on external stimuli of rewards and punishment to keep control.

The lead management system is based on choice theory (Glasser, 1996) which contends that all humans have five sources of internal motivation. These basic needs are:

1. Survival (physical needs)

2. Belonging

3. Power or Achievement

4. Freedom

5. Fun

When these needs are fulfilled at school, the impact on students is consistently positive. They behave better, learn more, and see education as valuable to them (Glasser \&Wubbolding, 1997).

When educators utilize the lead management approach, they create a school environment that is fun, friendly, and fair. They implement the following three principles:

\section{Principle One}

Elicit input from all students. Use the guidance curriculum program component to engage students in discussions on a variety of subjects relevant to them and their education. Specifically, ask students about what quality work is and how they would recognize it. Ask them about quality behavior. Ask them what they consider their best effort and what rules should be established for the classroom. Also, ask students how they think they can best learn the content of their classes. It is important for students to feel that the school counselors and teachers listen to them. 
Moreover, eliciting student input helps meet students' needs for power and freedom (Glasser \&Wubbolding, 1997). Lastly, ask students what rules should be established in the classroom, put them in writing, and ask all students to sign the paper indicating their agreement.

\section{Principle Two}

Learn to use the WDEP system of reality therapy (Glasser, 1965;Wubbolding,1988, 1991,1996). This system facilitates the implementation of choice theory in a lead management fashion. Choice theory teaches that beginning shortly after birth and continuing all our lives, we store information inside our minds and build a file of wants called our Quality World. This world is completely based on our wants and needs. It consists of images of people, activities, beliefs, possessions, and situations that fulfill one or more of our basic needs (Wubbolding, 2000). Choice theory also teaches that all behavior is chosen; therefore, it is purposeful. Behavior comes from the inside and is designed to close the gap between what individuals want at the time and what they perceive they are getting (Wubbolding, 2000).

\section{Principle Three}

Focus on meeting students' needs rather than controlling students' behavior. Ask fundamental questions about how to help students and faculty tap into the five basic human motivations; abandon questions about how to control students' behavior. When students' needs are met, their school experiences "feel good." Use faculty meetings to discuss possibilities for meeting students' needs. Relate the eagerness and appreciation students feel for athletics, art, drama, music, or other school activities to the academic curriculum. Ask why students are excited to learn and work in some areas but not in others. There are no simple answers; but there are answers (Glasser \&Wubbolding, 1997).

As stated previously, $84.44 \%$ of participants in this study strongly agreed, agreed, or somewhat agreed that school counselors should lead the effort to decrease the academic achievement gap in P-12 schools and 95.56\% of participants in this study strongly agreed, agreed, or somewhat agreed that it is important for school principals to support the efforts of school counselors as they work to decrease the academic achievement gap in P-12 schools. School counselors and school counseling programs are important to student success. A clear connection between school counseling programs and student academic achievement was made by Myrick (2003) who used a variety of examples to illustrate that developmental counseling programs positively impact student learning. School counselors can be effective leaders of student services through the implementation of the American School Counselor Association (ASCA) National Model. The ASCA National Model helped move school counseling from a responsive service provided for some students to a program for every student. This program reinforced the idea that school counselors help every student improve academic achievement, navigate personal and social development, and plan for successful careers after graduation (American School Counselor Association, 2006).

Comprehensive counseling programs have standards that identify the knowledge and skills students are expected to learn because of their involvement in the program. In addition to the time element, the organizational framework for the ASCA National Model includes the structural components and the program components (Gysbers \& Henderson, 2012). The structural elements (Vision Statement, Mission Statement, and Program Goals) describe the nature of the program and provide a philosophical basis for it. They clearly define the program, state the rationale for the program, and list the assumptions on which the program is based.

The techniques, methods, and resources that counselors employ to deliver the ASCA National Model are framed within four interactive program components: guidance curriculum, individual student planning, responsive services, and system support. These elements serve as organizers for the many guidance and counseling activities requiredinacomprehensive school counseling program. Each component makes specific contributions to enhance academic achievement, career decision making, and personal/social development for students (Gysbers\& Henderson, 2012).

Standards typically describe appropriate content for students to master over a specific range of grade levels. Guidance Curriculum lessons are developed and taught to help students understand the attitudes, beliefs, knowledge, and skills important to them as they progress from kindergarten to $12^{\text {th }}$ grade. Guidance Curriculum activities may be conducted in the classroom, guidance center, or other school facilities (Gysbers\& Henderson, 2012).

The Individual Student Planning component of the ASCA National Model assists students with developing and using individual learning plans. Within this component, students explore and evaluate their education, career options, and personal goals. The significance of the personalized learning is that it allows each student to understand who he/she is, what adult roles seem most desirable, and how to get there from where he/she is in the most productive way (National Association of Secondary School Principals, 2004). 
The Responsive Services component consists of activities designed to meet students' immediate needs and concerns. These services are designed to help students resolve academic, career, and personal/social issues. They are implemented through individual counseling, small-group counseling, consultation, or referral.

The System Support component provides administration and management activities that establish, maintain, and enhance activities in the other three program components. This is an indirect service for students. This component is typically implemented in the areas of research and development, professional development, staff and community public relations, community outreach, program management, community and advisory boards, and fair-share responsibilities (Gysbers\& Henderson, 2012).

In summary, $96.30 \%$ of all participants agree that school administrators should be specifically trained to impact the academic achievement gap in schools and $84.44 \%$ of all participants agree that school counselors should lead the effort to decrease the academic achievement gap in schools. These data seem to highlight the need to consider different measures to close the academic achievement gap in P-12 schools. These findings support the work of HolcombMcCoy (2007) who suggested that what goes on in schools can lessen the negative impact of societal problems.

Therefore, it seems reasonable to recommend the implementation of lead management training and the adoption of the ASCA National Model school counseling program for all school systems in the U.S. This should work from a financial standpoint as school systems usually have mandated in-service programs for all school personnel each year. More important, these proposed changes have the potential to enhance academic achievement for all students while also creating a better society.

\section{References}

Achievement Gap. (2011). Retrieved from http://www.edweek.org/issues/achievement-gap/index.html American School Counselor Association. (2006). Role statement: The school counselor.Alexandria, VA: Author.

Blasé, J., \& Blasé, J. (2000). Effective instructional leadership. Teachers perspectives on how principals promote teaching and learning in schools. Journal of EducationalAdministration, 38(2), 130-141.

Dahir, C.A., \& Stone, C. B. (2009). School counselor accountability: The path to social justiceand systemic change. Journal of Counseling and Development, 87, 12-20.

Dollarhide, C. T. (2003). School counselors as program leaders: Applying leadership contexts toschool counseling. Professional School Counseling, 6, 304-308.

Dufor, R. \& Marzano, R. J. (2011). Leadership is an affair of the heart. Leaders of learning: how district, school, and classroom leaders improve student achievement (pp. 193-208). Bloomington, IN: Solution Tree Press.

Duncan, A. (Director) (2013, February 28). Supporting and strengthening school leadership.National Association of Secondary School Principals National Conference. Lectureconductedfrom NASSP, National Harbor.

Editorial Projects in Education Research Center. (2011, July 7). Issues A-Z: Achievement gap.Education Week. Retrieved 08/29/2015 fromhttp:/www.edweek.org/ew/issues/achievement-gap/Equality of Educational Opportunity. (1966). Retrieved fromhttps://www.scribd.com/mobile/doc/89990298

Fensterwald, J. (2013, December). U.S. scores stagnant, other nations pass us by in latestinternational test. Retrieved fromhttp://edsource.org/2013/u-s-scores-stagnant-other-nations-pass-by-in-latest- international-c

Glasser, W. (1965). Reality therapy. New York, NY: Harper-Collins.

Glasser, W. (1990). The quality school. New York, NY: Harper-Collins.

Glasser, W. (1991). The quality school teacher. New York, NY: Harper-Collins.

Glasser, W. (1996). Choice theory. New York, NY: Harper-Collins.

Glasser, W., \&Wubbolding, R. (1997). Beyond blame: A lead management approach. RealityTherapy Training Manual (14th ed.). Cincinnati, OH: Center for Reality Therapy.

Gysbers, N. C., \& Henderson, P. (2012). Developing and managing your school guidance andcounseling program. Alexandria, VA: American Counseling Association.

Hatch, T., \& Bowers, J. (2002). The block to build on. ASCA School Counselor, 39, 12-21.

Haycock, K. (2001). Closing the achievement gap. Educational Leadership, 58, 6-11.

Henig, J. R., Hula, R. C., Orr, M., \&Pedescleaux, D. S. (1999)The color of school reform:Race, politics, and the challenge of urban education. Princeton, NJ: Princeton University Press.

Herr, E. L. (2001). The impact of national policies, economics, and school reform oncomprehensive guidance programs. Professional School Counseling, 4, 236-245.

Holcomb-McCoy, C. (2007). School counseling to close the achievement gap. Thousand Oaks,CA: Corwin Press.

Martin, P. J., \& House, R. M. (2002). Transforming school counseling in the transformingschool counseling initiative. Washington, DC: The Education Trust. 
Marzano, R. J., Waters, T., \& McNulty, B. A. (2005). The 21 responsibilities of the schoolleader. School leadership that works from research to results (pp. 41-64). Alexandria,VA: Association for Supervision and Curriculum Development.

Myrick, L. (2003). Group effort. Counseling Today, 57, (12), 30-37National Association of Secondary School Principals. (2004). Breaking ranks II: Strategies forleading high school reform. Reston, VA: Author.

Washington State Legislature. (2008). Educational inequality: A growing crisis. Report of the HB2722 Advisory Committee. Retrieved from http://www.us/publications

Wubbolding, R. (1988). Using reality therapy. New York, NY: Harper-Collins.

Wubbolding, R. (1991). Understanding reality therapy. New York, NY: Harper-Collins.

Wubbolding, R. (1996). Reality therapy training (9th ed.). Cincinnati, OH: Center for RealityTherapy.

Wubbolding, R. (2000). Reality therapy for the $21^{\text {st }}$ century. Philadelphia, PA:Brunner-Routledge. 